\title{
Pengaruh Efektivitas SIA dan Komitmen Organisasi Pada Kinerja Karyawan dengan Locus Of Control Sebagai Pemoderasi
}

\author{
Dewa Putu Aditya Darma Putra ${ }^{1}$ \\ Maria M. Ratna Sari ${ }^{2}$ \\ ${ }^{1}$ Fakultas Ekonomi dan Bisnis Universitas Udayana (Unud), Bali - Indonesia \\ email: adityadarmaputra22@gmail.com / Telp: +6285205520833 \\ ${ }^{2}$ Fakultas Ekonomi dan Bisnis Universitas Udayana (Unud), Bali - Indonesia
}

\begin{abstract}
ABSTRAK
Sumber Daya Manusia merupakan faktor paling menentukan keberhasilan suatu organisasi. Keberhasilan perusahaan ditentukan oleh tercapainya hasil yang baik oleh kinerja karyawan. Variabel Independen dalam penelitian ini adalah Efektivitas Sistem Informasi Akuntansi dan Komitmen Organisasi. Locus Of Control sebagai variabel moderasi dan Kinerja Karyawan sebagai variabel dependen. Penelitian ini dilakukan di Kantor Perwakilan Bank Indonesia Provinsi Bali. Sampel dalam penelitian ini adalah karyawan bagian kliring di Bank Peserta Kliring Kota Denpasar Bali. Metode yang digunakan adalah nonprobability sampling dengan teknik sampel jenuh. Hasil pengujian hipotesis dengan analisis regresi linear berganda dan Moderating Regression Analysis menunjukan Efektivitas Sistem Informasi Akuntansi dan Komitmen Organisasi berpengaruh positif pada Kinerja Karyawan, Locus Of Control tidak mampu memoderasi pengaruh Efektivitas Sistem Informasi Akuntansi pada Kinerja Karyawan dan Locus Of Control mampu memoderasi pengaruh Komitmen Organisasi pada Kinerja Karyawan.
\end{abstract}

Kata Kunci: Efektivitas sistem informasi akuntansi, komitmen organisasi, locus of control, kinerja karyawan.

\begin{abstract}
Human Resources is the most decisive resource for organization's success. The success of the company is determined by the achievement of good results by employee performance. Independent variables in this study is the Effectiveness of Accounting Information Systems and Organizational Commitment. This research was conducted at Bank Indonesia Office of Bali Province. The sample in this research is employees of clearing section at Bank Participant Clearing of Denpasar, Bali. The method used is nonprobability sampling with saturated sample technique. The results of hypothesis testing with multiple linear regression analysis and Moderating Regression Analysis show the effectiveness of Accounting Information System and Organizational Commitment positively influence on Employee Performance, Locus Of Control unable to moderate influence Effectiveness of Accounting Information System on Employee Performance and Locus Of Control able to moderate influence Organizational commitment to Employee Performance.
\end{abstract}

Keywords: Effectiveness of accounting information system, organizational commitment, locus of control, employee performance 


\section{PENDAHULUAN}

Perkembangan yang terjadi di bidang ilmu pengetahuan serta bidang teknologi sangatlah pesat. Perkembamgan ini mengakibatkan, semua perusahaan bersaing untuk menunjukan serta menaikan tingkat kinerja mereka. Sumber Daya Manusia merupakan faktor yang paling menentukan keberhasilan suatu organisasi. Suatu organisasi harus memiliki nilai lebih dibandingkan dengan organisasi lainnya. Organisasi dikatakan berhasil apabila dapat menarik perhatian atas kelebihan yang dimilikinya dibandingkan dengan organisasi lainKondisi ekonomi yang sedang dihadapi Indonesia pada tahun ini mengalami perlambatan, yang dikarenakan pertumbuhan ekonomi global yang sedang melemah. Selain itu, untuk faktor internal yang sedang di hadapi oleh Indonesia adalah perlambatan di bidang ekonomi yang hampir terjadi di seluruh Provinsi, tingginya kepemilikan asing pada Surat Utang Negara, dan kemampuan membayar hutang menurun ditengah melemahnya ekspor. Ini juga mengakibatkan kinerja perbankan mengalami penurunan. Akan tetapi ini tidak menyurutkan persaingan antar perbankan, yang dimana ini mengisyaratkan untuk mengoptimalisasi kinerja karyawan, khususnya kinerja karyawan bagian kliring yang ada di perbankan. Salah satu bagian di perbankan yang akan di teliti oleh peneliti adalah karyawan bagian kliring pada bank peserta kliring di daerah Bali. Penelitian ini dilakukan pada bagian tersebut, dikarenakan bagian kliring adalah bagian yang penting di dalam perbankan dan memiliki peranan yang sangat penting dalam proses kelancaran sistem pembayaran moneter dalam mempengaruhi sistem pelayanan pembayaran moneter baik dalam sisi memajukan ataupun memperlancar lalu lintas 
pembayaran giral antar bank di seluruh Indonesia.

Kinerja perbankan di Indonesia mengalami penurunan hal itu dapat dilihat dari Utang Luar Negeri (ULN) pada akhir triwulan I 2017 berada pada posisi USD326,3 miliar tumbuh sebesar 2,9\% atau sedikit meningkat dibanding triwulan sebelumnya yang sebesar 2,0\%. (www.bi.go.id). Fenomena tersebut merupakan alasan peneliti untuk melakukan penelitian ini. Kinerja karyawan suatu perusahaan di bidang perbankan dalam hal ini khususnya kinerja karyawan bagian kliring menjadi hal yang sangat penting untuk dilihat, ini dikarenakan kinerja karyawan yang baik akan menunjukan bahwa sebuah perusahaan tersebut memiliki tingkat kinerja yang baik pula. Dengan volume rata-rata harian lebih dari 300.000 lembar transaksi menunjukan bahwa kliring sangat dibutuhkan sebab kecepatan dalam dunia perdagangan jauh lebih cepat dari pada waktu yang dibutuhkan guna melengkapi pelaksanaan aset transaksi dan kliring berperan sangat penting bagi aktivitas dan pendapatan di suatu bank.

Kinerja merupakan tingkat pencapaian hasil atas terlaksananya tugas tertentu. Sedangkan kinerja perusahaan merupakan tingkat pencapaian hasil dalam rangka mewujudkan tujuan perusahaan. Kinerja individu, kinerja kelompok dan kinerja perusahaan dipengaruhi oleh banyak faktor internal dan eksternal organisasi (Simanjuntak,2011).Faktor yang berpengaruh terhadap kinerja yaitu faktor individu : kemampuan, ketrampilan, latar belakang keluarga, pengalaman kerja, tingkat sosial dan demografi seseorang. Kemudian faktor psikologis : persepsi, peran, sikap kerja, kepribadian, motivasi dan kepuasan kerja , Faktor organisasi : struktur organisasi, desain pekerjaan, kepemimpinan, sistem 
penghargaan Gibson (1987).

Kemajuan dan perkembangan teknologi di era globalisasi yang diiringi dengan perkembangan sistem informasi berbasis teknologi menjadi suatu hal yang penting. Hal tersebut telah memberikan pengaruh yang signifikan terhadap penerapan sistem informasi akuntansi di dalam suatu organisasi. Sistem informasi akuntansi dianggap sebagai faktor penting dalam pencapaian kinerja yang lebih besar terutama dalam proses pengambilan keputusan (Al-eqab and Adel, 2013). Sistem informasi akuntansi dapat dikatakan efektif jika sistem mampu menghasilkan informasi yang dapat diterima dan mampu memenuhi harapan informasi secara tepat waktu (timely), akurat (accurate), dan dapat dipercaya (reliabel) (Widjajanto, 2001).

Komitmen karyawan kepada perusahaan dipandang sangat penting dalam bisnis. Dalam setiap perilaku organisasional pasti membahas arti pentingnya komitmen karyawan. Semakin tinggi komitmen karyawan maka semakin baik kinerja karyawan.Namun terkadang suatu perusahaan atau organisasi kurang memperhatikan komitmen yang ada terhadap karyawannya, sehingga berdampak terhadap kinerja terhadap karyawan ataupun loyalitas karyawan menjadi berkurang.

Terdapat beberapa faktor yang mungkin mempengaruhi kinerja karyawan tersebut. Peneliti menggunakan variabel efektivitas sistem informasi akuntansi dan komitmen organisasi di dalam melakukan pengujian untuk menguji kinerja karyawannya.Menurut Jogiyanto (2009:227), sistem informasi akuntansi merupakan suatu sistem dimana mampu mengolah data transaksi bisnis menjadi 
informasi keuangan untuk keperluan para pemakainnya. Menurut Mathieu dan Zajac (1990) menyatakan bahwa komitmen organisasi merupakan ikatan keterkaitan anatara individu dengan organisasi. Angel dan Perry (1981) dalam Venusita (2006) menyatakan bahwa komitmen organisasi yang kuat yang dimiliki oleh individu akan menyebabkan individu berusaha keras mencapai tujuan organisasi sesuai dengan tujuan dan kepentingan organisasi. Wiener (1982) menyatakan bahwa komitmen organisasi didefinisikan sebagai dorongan dari dalam individu untuk melakukan sesuatu agar dapat menunjang keberhasilan organisasi sesuai dengan tujuan yang ditetapkan dan lebih mengutamakan kepentingan organisasi.

Penelitian ini dilakukan, karena adanya ketidakkonsistenan hasil dari penelitian terdahulu. Hasil penelitian Panggeso (2014), Astuti (2014), dan Mercika (2015) menunjukkan efektivitas SIA berpengaruh positif terhadap kinerja karyawan. Namun di sisi lain terdapat juga penelitian yang menunjukkan bahwa pengadopsian SIA tidak dapat meningkatkan kinerja, profitabilitas dan efisiensi operasi seperti pada penelitian Urquia et al., (2010), Kouser et al., (2011) dan Kharuddin et al., (2010). Yuleova (2013) mengemukakan adanya pengaruh positif anatara komitmen organisasi dengan kinerja pegawai melalui kepuasan kerja sejalan dengan Pahmi, Idrus dan Mahlia (2011) menemukan bahwa komitmen organisasi berpengaruh positif terhadap kinerja karyawan. Sedangkan Carmeli dan Freund (2006) menemukan bahwa komitmen organisasi tidak berpengaruh terhadap kinerja pegawai. Berdasarkan penelitian terdahulu pula, peneliti menambahkan variabel locus of controlsebagai variabel moderasi yang bertujuan 
mempertegas hubungan antara efektivitas sistem informasi akuntansi, komitmen organisasi dengan kinerja karyawan itu sendiri. Variabel locus of control merupakan determinan yang penting didalam cara seseorang untuk menginterprestasikan situasi atau keadaan yang sedang dia hadapi (Rotter, 1966).

Brownell (1981) membagi locus of control menjadi dua, yakti internal locus of control dan external locus of control. internal locus of control adalah keyakinan seorang individu bahwa mereka memegang kendali atas peristiwaperistiwa yang mereka alami. Sedangkan, external locus of control merupakan tingkat kepercayaan yang dimiliki seseorang di dalam dirinya yang meyakini bahwa segala sesuatu yang terjadi pada mereka dikendalikan oleh kekuatan yang berasal dari luar dirinya.

Sistem informasi akuntasi yang ada di dalam organisasi atau perusahaan seringkali menjadi hal yang sangat penting bagi efektivitas seseorang karyawan dalam bekerja di suatu perusahaan. Asriningsing (2015) menyatakan bahwa efektivitas penggunaan atau pengimpletasian teknologi sistem informasi dalam suatu perusahaan dapat dilihat dari kemudahan pemakai dalam mengidentifikasi data, ,mengakses data, dan menginteprestasikan data tersebut. Teori Technologyto-Performance Chain (TPC) menyatakan suatu teknologi mempunyai dampak positif pada kinerja individual karena dengan adanya teknologi akan sangat mendukung bagi penyelesaian tugas setiap individu dan berdampak pada kinerja yang dihasilkan.Penelitian yang dilakukan Antasari (2015), Suartini (2015) menyatakan bahwa efektivitas sistem informasi akuntansi berpengaruh positif terhadap kinerja individual. Penelitian yang dilakukan oleh Sugiantara (2017) 
menyatakan terdapat pengaruh positif antara variabel efektivitas penerapan sistem informasi akuntansi terhadap kinerja karyawan.

Komitmen seseorang karyawan pada organisasi atau perusahaan di dalam dunia kerja seringkali menjadi suatu isu yang sangat penting.Menurut penelitian yang dilakukan oleh Ghorbanpour, Dehnavi, Forough Heyrani (2014) dan Hueryren Yeh, Hong (2012) Komitmen organisasi memiliki pengaruh positif yang signifikan pada kinerja karyawan.Pengendalian diri individu dalam suatu situasi (locus of control) dalam menerapkan sistem informasi akuntansi untuk menopang kinerja agar lebih efektif menjadi sesuatu yang sangat penting. Ginanda (2016) melakukan penelitian tentang sistem informasi akuntasi dan locus of control terhadap kinerja karyawan dan mendapatkan hasil berpengaruh positif signifikan. Jika seorang individu bisa menerapkan sistem informasi akuntansi secara efektif dan mengontrol segala sesuatu yang dihadapinya maka kinerja yang dihasilkan akan lebih baik.

Berdasarkan uraian diatas maka hipotesis yang dapat dirumuskan adalah:

$\mathrm{H}_{1}$ : Efektivitas sistem informasi akuntansi berpengaruh positif pada kinerja karyawan.

$\mathrm{H}_{2}$ : Komitmen organisasi berpengaruh positif pada kinerja karyawan.

$\mathrm{H}_{3}$ : Locus of control tidak mampu memoderasi pengaruh antara efektivitas sistem informasi akuntansi pada kinerja karyawan.

$\mathrm{H}_{4}$ : Locus of control mampu memoderasi pengaruh antara komitmen organisasi pada kinerja karyawan.

\section{METODE PENELITIAN}

Penelitian ini menggunakan pendekatan kualitatif. Penelitian ini dilakukan dengan tujuan untuk menganalisis hubungan antara efektivitas sistem informasi akuntansi, komitmen organisasi pada kinerja karyawan dengan locus of 
controlsebagai variabel pemoderasi. desain dalam penelitian ini ditunjukan oleh gambar dibawah.

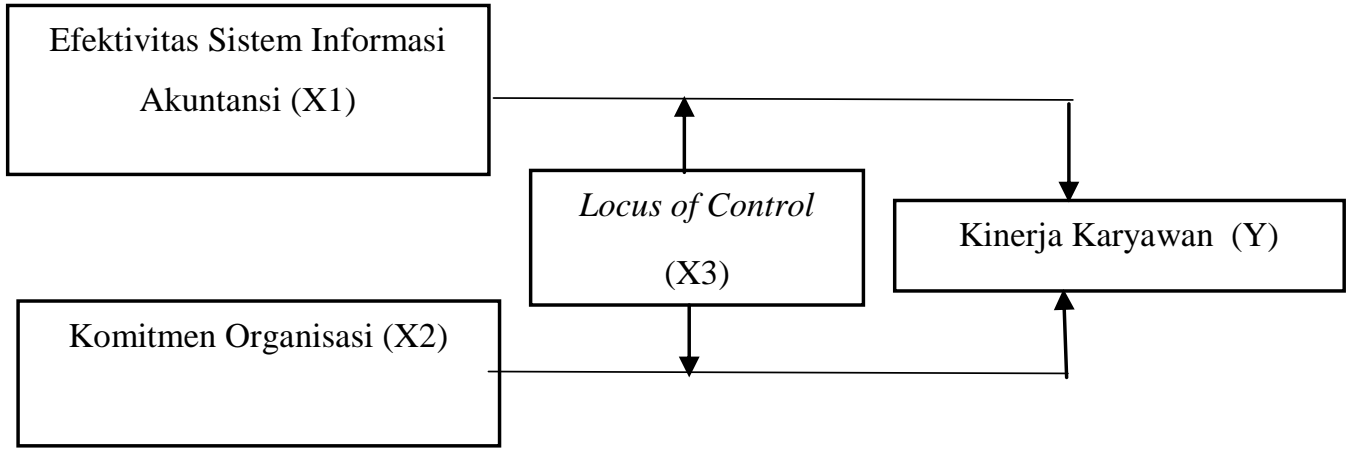

\section{Gambar 1. Desain Penelitian}

Lokasi penelitian ini yaitu di Bank Indonesia yang berada di Kota Denpasar Bali. Variabel yang digunakan dalam penelitian ini adalah efektivitas sistem informasi akuntansi $\left(\mathrm{X}_{1}\right)$ dan komitmen organisasi $\left(\mathrm{X}_{2}\right)$ sebagai variabel bebas, kinerja karyawan (Y) sebagai variabel terikat dan locus of control $\left(\mathrm{X}_{3}\right)$ sebagai variabel moderasi.Populasi dalam penelitian ini adalah seluruh karyawan bagian kliring di bank peserta kliring di Kota Denpasar Bali sebanyak 70 karyawan. Teknik pengambilan sampel dilakukan dengan total sampling atau sampel jenuh, yaitu teknik sampling yang dilakukan dengan cara mengambil seluruh populasi sebagai sampel. Teknik ini dipilih agar peneliti mendapatkan seluruh persepsi dan jawaban dari karyawan bagian kliring pada setiap bank peserta kliring dan melihat jumlah dari populasi yang tergolong kecil, sehingga seluruh populasi digunakan sebagai sampel dalam penelitian ini. 
Metode pengumpulan data dalam penelitian ini adalah metode survei dengan menyebarkan kuesioner kepada para responden. Kuisioner yang diberikan berupa beberapa pernyataan yang akan dijawab oleh responden tersebut. Hasil jawaban kuisioner dari para responden akan diukur menggunakan skala likert 1 sampai dengan 5. Teknik analisis data yang digunakan dalam penelitian ini adalah uji validitas dan reliabilitas, uji asumsi klasik yang terdiri dari uji normalitas, multikolonieritas dan heteroskedastisitas, uji regresi linear berganda, uji Moderating Regression Analysis (MRA) dan pengujian hipotesis yang terdiri dari koefisien determinasi $\left(\mathrm{R}^{2}\right)$, goodness of fit (Uji F) dan uji parsial (uji t).

Efektivitas sistem didasarkan pada kontribusinya dalam pembuatan keputusan, kualitas informasi akuntansi, evaluasi kinerja, pengendalian internal yang memfasilitasi transaksi perusahaan (Sajady dan Hashem, 2008). Efektivitas SIA adalah suatu keberhasilan atas penggunaan sistem informasi akuntansi dalam menghasilkan informasi yang berkualitas sehingga dapat mendukung pengambilan keputusan yang tepat bagi suatu organisasi. Kuisioner yang digunakan dalam penelitian ini merupakan adopsi dari Astuti (2014) yang sudah dilakukan beberapa modifikasi oleh peneliti. Efektivitas sistem informasi akuntansi diukur menggunakan lima indikator antara lain, (1) keamanan data, (2) waktu, (3) ketelitian, (4) relevansi dan (5) variasi laporan.

Robbins dan Timothy (2008) mendefinisikan komitmen organisasi sebagai suatu keadaan yang dimana seorang karyawan tersebut memihak organisasinya serta tujuan-tujuan dan keinginannya untuk mempertahankan keanggotaan dalam organisasi tersebut. Komitmen organisasi merupakan nilai personal, yang 
Dewa Putu Aditya Darma Putra dan Maria M. Ratna Sari. Pengaruh...

mengacu pada sikap loyalitas atau sebuah komitmen kepada perusahaan. Komitmen menghadirkan sesuatu diluar loyalitas belaka terhadap suatu organisasi, akan tetapi juga meliputi suatu hubungan yang aktif dengan organisasi dimana individu bersedia untuk bersedia memberikan sesuatu dari diri mereka untuk membantu keberhasilan dan kemakmuran organisasi. Kuisioner yang diginakan dalam penelitian ini merupakan adopsi dari Basudewa (2015) yang sudah dilakukan beberapa modifikasi oleh peneliti. Komitmen organisasi diukur menggunakan tujuh indikator antara lain, (1) berusaha lebih keras untuk organisasi, (2) bersedia menerima semua bentuk penugasan, (3) organisasi dapat memberikan inspirasi kepada individu tersebut, (4) organisasi tempat ia bekerja merupakan tempat yang terbaik, (5) peduli akan nasib dari organisasinya, (6) merasa menjadi bagian dari organisasi dan (7) tidak ingin mengundurkan diri dari organisasi.

Menurut Simamora (2003:45) kinerja adalah ukuran keberhasilan organisasi dalam mencapai misinya. Mangkunegara (200:67) berpendapat kinerja karyawan adalah prestasi kerja hasil kerja (output) baik kualitas maupun kuantitas yang dicapai karyawan dalam melaksanakan tugas kerjanya sesuai dengan tanggungjawab yang diberikan kepadanya. Kinerja karyawan juga merupakan performance atau kinerja yang berarti hasil kerja yang dapat dicapai oleh seseorang dalam suatu perusahaan sesuai dengan wewenang dan tanggung jawab masing-masing dalam upaya pencapaian tujuan perusahaan secara legal, tidak melanggar hukum dan tidak bertentangan dengan moral atau etika baik hasil kerja secara kualitas dan kuantitas yang dicapai oleh seorang pegawai dalam 
melaksanakan tugasnya sesuai dengan tanggung jawab yang diberikan kepadanya. Kuisioner digunakan dalam mengukur variabel kinerja karyawan di dalam penelitian ini. Kuisioner yang digunakan oleh peneliti merupakan kuisioner dari Astuti (2014) dan Ratna (2015) yang sudah dilakukan beberapa modifikasi oleh peneliti. Terdapat sembilan indikator di dalam pengukuran variabel kinerja karyawan yaitu, (1) produktivitas, (2) Efektivitas , (3) kuantitas kerja, (4) waktu penyelesaian tugas, (5) hasil dari pekerjaan.

Hapsari (2010) menyatakan locus of control merupakan keyakinan yang dimiliki oleh seorang individu apakah individu tersebut dapat atau tidak untuk mengendalikan kejadian yang mempengaruhi individu tersebut. Spector (2005) menyatakan bahwa individu yang percaya bahwa mereka dapat mengontrol suatu kejadian yang ada dalam hidup mereka, itu berarti cenderung memiliki internal locus of control. Mereka yang percaya bahwa nasib, keberuntungan, atau orang lain yang mengontrol hidup mereka dianggap memiliki external locus of control. Maria A. (2013) menyatakan bahwa locus of control merupakan suatu pembangunan kepribadian dari seorang individual. Locus of control adalah keyakinan yang dimiliki oleh seorang individu apakah individu tersebut dapat atau tidak mengendalikan kejadian yang mempengaruhi individu tersebut. Variabel locus of control dalam penelitian ini diukur dengan menggunakan kuisioner yang diadopsi dari Widyawati (2016) serta menggunakan lima indikator di dalam pernyataan yang ada di kuisioner tersebut. Indikator yang digunakan yaitu, (1) mendapatkan pekerjaan merupakan hal keberuntungan, (2) mampu mengerjakan tugas dengan baik jika berusaha, (3) memiliki upaya untuk mengontrol 
lingkungannya., (4) percaya bahwa mampu menghadapi situasi yang penuh dengan tekanan, (5) tidak ada yang disebut dengan keberuntungan.

Sebelum melakukan analisis data terlebih dahulu diawali dilakukan pengujian terhadap instrumen penelitian yaitu dengan melaksanakan uji validitas dan uji reliabilitas. Instrumen yang dapat digunakan untuk penelitian adalah instrumen yang dinyatajkan valid dan reliabel. kuisioner dikatakan valid apabila pernyataan pada kuisioner mampu mengungkapkan sesuatu yang akan diukur oleh kuisioner tersebut Tingkat reliabilitas dengan metode Alpha Croancbach's diukur berdasarkan skala 0 sampai dengan 1 (Ghozali, 2016). Sedangkan pada uji reliabilitas terdapat ketentuan dalam mengukur reliabilitas menurut dalam Ghozali (2016) yaitu suatu konstruk atau variabel dapat dikatakan reliabel jika memberikan nilai Cronbach Alfa> 0,70. Suatu kuisioner dikatakan reliable apabila jawaban responden terhadap pernyataan adalah konsisten dan tetap dari waktu ke waktu (Ghozali, 2016).

Uji asumsi klasik terhadap model regresi yang digunakan dalam penelitian dilakukan untuk menguji apakah model regresi tersebut baik atau tidak. Dalam penelitian ini, uji asumsi klasik yang digunakan adalah uji normalitas, uji multikolonieritas dan heteroskedastisitas. Untuk pengujian asumsi klasik diawali dengan uji normalitas dimana apabila nilai Asymp.Sig (2-tailed) $>\alpha(0,05)$ maka dapat disimpulakan data terdistribusi normal (Ghozali, 2016). Pengujian ada atau tidaknya multikolonieritas di dalam model regresi dapat dilakukam dengan melihat nilai tolerance dan nilai variance inflation factor (VIF). Namun yang umum dipakai untuk menunjukan adanya multikolonieritas adalah nilai 
tolerance $<0,10$ atau VIF $>10$ (Ghozali, 2016). Untuk mendeteksi ada atau tidaknya heteroskedastisitas dapat dilakukan dengan melihat grafik plot antara nilai prediksi variabel terikat (dependent) dengan residualnya, jika ada pola yang jelas, serta titik-titik yang menyebar di atas dan di bawah angka 0 pada sumbu Y, maka tidak terjadi heteroskedastisitas.

Setelah dilakukan uji asumsi klasik, selanjutnya dilakukan uji statistik deskriptif guna menyajikan informasi mengenai karakteristik variabel yang diteliti. Statistik deskriptif menunjukan informasi mengenai jumalah pengamatan, nilai minimum, nilai maksimum, nilai mean, dan standar deviasi. Uji kesesuaian model (goodness of fit test), uji ini digunakan untuk menguji persamaan model struktual yang diusulkan memiliki kesesuaian (fit) dengan data atau tidak. Penelitian ini, dalam pengujian goodness of fit akan diuji melalui uji $\mathrm{F}$ yang jika $\mathrm{F}_{\text {hitung }}>\mathrm{F}_{\text {tabel }}$ dan nilai probabilitas $\mathrm{Sig}$ atau $(0,05>\mathrm{Sig})$, sehingga $\mathrm{H}_{0}$ ditolak dan $\mathrm{H}_{\mathrm{a}}$ diterima yang mempunyai arti bahwa model persamaan struktural telah signifikan dengan data yang diperoleh. Hal tersebut berbeda, jika $F_{\text {hitung }} \leq F_{\text {tabel }}$ dan nilai probabilitas 0,05 lebih kecil dari nilai probabilitas $\mathrm{Sig}$ atau $(0,05 \leq \mathrm{Sig})$, maka $\mathrm{H}_{0}$ diterima dan $\mathrm{H}_{\mathrm{a}}$ ditolak yang artinya model persamaan struktural tidak signifikam dengan data yang diperoleh (Utama, 2016:82). Koefisien determinasi $\left(\mathrm{R}^{2}\right)$ digunakan untuk mengukur besarnya kontribusi variabel bebas terhadap variabel terikat secara bersamaan (gabungan) dan untuk mengetahui ketepatan alat analisis data.Pengujian secara parsial (Uji t) digunakan untuk mengetahui apakah signifikan analisis jalur dengan membandingkan antara nilai probabilitas 0,05 dengan nilai probabilitas Sig atau $(0,05 \leq \mathrm{Sig})$, sehingga $\mathrm{H}_{0}$ diterima dan $\mathrm{H}_{\mathrm{a}}$ 
ditolak yang menyatakan tidak adanya signifikan. Hal yang berbeda jika nilai probabilitas 0,05 lebih besar dari nilai probabilitas Sig atau $(0,05>\mathrm{Sig})$, maka $\mathrm{H}_{0}$ ditolak dan $\mathrm{H}_{\mathrm{a}}$ diterima, yang mempunyai arti signifikan (Utama, 2016:81). Pengujian Moderating Regression Analysis (MRA)merupakan teknik analisis data yang digunakan untuk mengetahui pengaruh variabel independen terhadap variabel dependennya dan kemampuan variabel pemoderasi dalam memoderasi pengaruh variabel independen terhadap variabel dependennya. MRA merupakan analisis regresi linear berganda yang mengandung unsur interaksi, yaitu perkalian dua atau lebih variabel independen (Utama, 2014). Model persamaan regresi dalam penelitian ini adalah sebagai berikut:

$Y=\alpha+\beta_{1} X_{1}+\beta_{2} X_{2}+\beta_{3} X_{3}+\beta_{4} X_{1} X_{3}+\beta_{5} X_{2} X_{3}+e$

Keterangan:

Y : Kinerja Karyawan

$\mathrm{X}_{1} \quad$ : Efektivitas Sistem Informasi Akuntansi

$\mathrm{X}_{2} \quad$ : Komitmen Organisasi

$\mathrm{X}_{3} \quad$ : Locus Of Control

$\alpha \quad$ : Konstanta

$\beta_{1}-\beta_{5}:$ Koefisien Regresi

e : error

\section{HASIL DAN PEMBAHASAN}

Teknik Penelitian ini menggunakan instrumen berupa kuesioner yang disebarkan secara langsung ke Kantor Perwakilan Bank Indonesia Daerah Bali, responden dalam penelitian ini adalah karyawan bagian kliring di Bank Peserta Kliring Kota Denpasar Bali. Jumlah kuesioner yang disebarkan sebanyak 70 kuesioner. Kuesioner yang tidak kembali sebanyak 4 kuesioner dan yang kembali sebanyak 66 kuesioner. 
Statistik deskriptif menyajikan informasi mengenai karakteristik variabel yang diteliti. Statistik deskriptif menunjukan informasi mengenai jumalah pengamatan, nilai minimum, nilai maksimum, nilai mean, dan standar deviasi.

Tabel 1.

Hasil Statistik Deskriptif

\begin{tabular}{lccccc}
\hline \multicolumn{1}{c}{ Variabel } & N & $\begin{array}{c}\text { Nilai } \\
\text { Minimum }\end{array}$ & $\begin{array}{c}\text { Nilai } \\
\text { Maximum }\end{array}$ & Rata-rata & $\begin{array}{c}\text { Standar } \\
\text { Deviasi }\end{array}$ \\
\hline $\begin{array}{l}\text { Efektivitas Sistem } \\
\text { Informasi Akuntansi }\end{array}$ & 66 & 5,93 & 19,93 & 14,97 & 4,29 \\
$\left(\mathrm{X}_{1}\right)$ & & & & & \\
$\begin{array}{l}\text { Komitmen Organisasi } \\
\left(\mathrm{X}_{2}\right)\end{array}$ & 66 & 7,00 & 26,72 & 20,36 & 6,00 \\
Locus Of Control $\left(\mathrm{X}_{3}\right)$ & 66 & 5,85 & 19,11 & 14,03 & 4,39 \\
Kinerja Karyawan (Y) & 66 & 5,00 & 19,97 & 14,34 & 4,32 \\
\hline Sumber: Data diolah, 2017 & & & & &
\end{tabular}

Berdasarkan tabel 1. Variable efektivitas sistem informasi akuntansi $\left(\mathrm{X}_{1}\right)$ memiliki nilai minimum sebesar 5,93, nilai maksimum 19,93, dengan nilai ratarata 14,97. Standar deviasi pada variabel efektivitas sistem informasi akuntansi adalah sebesar 4,29. Hal ini menunjukan bahwa standar penyimpangan data terhadap nilai rata-ratanya adalah 4,29. Variabel komitmen organisasi $\left(\mathrm{X}_{2}\right)$ memiliki nilai minimum 7,00, nilai maksimum 26,72, dengan nilai rata-rata 20,36. Standar deviasi pada variabel komitmen organisasi adalah sebesar 6,00. Hal ini menunjukan bahwa standar penyimpangan data terhadap nilai rata-ratanya adalah 6,00. Variabel locus of control $\left(\mathrm{X}_{3}\right)$ memiliki nilai minimum 5,85, nilai maksimum 19,11, dengan nilai rata-rata 14,03. Standar deviasi variabel locus of control adalah sebesar 4,39. Hal ini menunjukan bahwa standar penyimpangan 
Dewa Putu Aditya Darma Putra dan Maria M. Ratna Sari. Pengaruh...

data terhadap nilai rata-ratanya adalah 4,39. Variabel Kinerja Karyawan (Y) memiliki nilai minimum 5,00, nilai maksimum 19,97, dengan nilai rata-rata 14,34. Standar deviasi variabel kinerja karyawan adalah sebesar 4,32. Hal ini menunjukan bahwa standar penyimpangan data terhadap nilai rata-ratanya adalah 4,32 .

Pengujian validitas dilakukan dengan menghitung nilai Pearson Correlation. Suatu instrumen akan dikatakan valid apabila nilai Pearson Correlation terhadap skor total di atas 0,30 (Sugiyono, 2014:187)

Tabel 2.

Hasil Uji Validitas

\begin{tabular}{|c|c|c|c|c|}
\hline No. & Variabel & Kode Instrumen & $\begin{array}{l}\text { Pearson } \\
\text { Correlation }\end{array}$ & Ket \\
\hline \multirow[t]{5}{*}{1} & Efektivitas & $\mathrm{X} 1.1$ & 0,919 & Valid \\
\hline & Informasi Akuntansi $\left(\mathrm{X}_{1)}\right.$ & $\mathrm{X} 1.2$ & 0,880 & Valid \\
\hline & & $\mathrm{X} 1.3$ & 0,922 & Valid \\
\hline & & $\mathrm{X} 1.4$ & 0,875 & Valid \\
\hline & & $\mathrm{X} 1.5$ & 0,912 & Valid \\
\hline \multirow[t]{7}{*}{2} & Komitmen & $\mathrm{X} 2.1$ & 0,813 & Valid \\
\hline & $\left(\mathrm{X}_{2}\right)$ & $\mathrm{X} 2.2$ & 0,857 & Valid \\
\hline & & $\mathrm{X} 2.3$ & 0,898 & Valid \\
\hline & & $\mathrm{X} 2.4$ & 0,903 & Valid \\
\hline & & $\mathrm{X} 2.5$ & 0,853 & Valid \\
\hline & & $\mathrm{X} 2.6$ & 0,819 & Valid \\
\hline & & $\mathrm{X} 2.7$ & 0,846 & Valid \\
\hline \multirow[t]{5}{*}{3} & Locus Of Control $\left(\mathrm{X}_{3}\right)$ & $\mathrm{X} 3.1$ & 0,899 & Valid \\
\hline & & $\mathrm{X} 3.2$ & 0,882 & Valid \\
\hline & & X3.3 & 0,921 & Valid \\
\hline & & X3.4 & 0,802 & Valid \\
\hline & & X3.5 & 0,891 & Valid \\
\hline \multirow[t]{5}{*}{4} & Kinerja Karyawan (Y) & Y1 & 0,898 & Valid \\
\hline & & Y2 & 0,927 & Valid \\
\hline & & Y3 & 0,823 & Valid \\
\hline & & Y4 & 0,849 & Valid \\
\hline & & Y5 & 0,905 & Valid \\
\hline
\end{tabular}


Pengujian reliabilitas terhadap instrumen dilakukan dengan melihat koefisien croncbach's alpha. Jika nilai croncbach's alpha lebih besar dari 0,70 maka intrumen yang digunakan tergolong reliabel.

Tabel 3.

Hasil Uji Reliabilitas

\begin{tabular}{llll}
\hline No & \multicolumn{1}{c}{ Variabel } & croncbach's alpha & Keterangan \\
& & & Reliabel \\
\hline 1 & Efektivitas Sistem Informasi Akuntansi & 0,940 & \\
& $\left(\mathrm{X}_{1}\right)$ & 0,939 & Reliabel \\
2 & Komitmen Organisasi $\left(\mathrm{X}_{2}\right)$ & 0,926 & Reliabel \\
3 & Locus Of Control $\left(\mathrm{X}_{3}\right)$ & 0,928 & Reliabel \\
4 & Kinerja Karyawan $(\mathrm{Y})$ & &
\end{tabular}

Hasil pengujian data menunjukan bahwa nilai croncbach's alpha lebih besar dari 0,70 hal ini menunjukan bahwa data penelitian dinyatakan reliabel

Uji statistik yang digunakan untuk menguji normalitas dalam penelitian ini adalah uji statistik non-parametrik Kolmogorov-Smirnov (K-S). Data penelitian dikatakan berdistribusi normal apabila nilai Asymp. Sig (2-Tailed) lebih besar daripada level of signifcant yang dipakai yaitu 0,05 . Berdasarkan hasil uji, nilai signifikansi untuk persamaan model pertama adalah sebesar 0,063 $(0,063>0,05)$ dan nilai signifikansi untuk persamaan model kedua adalah sebesar 0,056 (0,056 > 0,05). Hal ini menunjukan bahwa model regresi yang digunakan pada penelitian ini berdistribusi normal. Berdasarkan hasil uji multikolinearitas, dapat dilihat nilai tolerance lebih besar dari $10 \%(0,10)$ dan nilai VIF kurang dari 10 , maka model regresi dikatakan bebas dari multikolinearitas.Berdasarkan hasil uji heteroskedastisitas dengan uji glejser, nilai signifikansi masing-masing variabel 
lebih besar dari 0,05 . Hal ini menunjukan bahwa seluruh variabel tersebut bebas dari heteroskedastisitas.

Analisis regresi linear berganda merupakan model yang digunakan untuk menganalisis pengaruh lebih dari satu variabel independen terhadap satu variabel dependen.

Tabel 4.

Hasil Analisis Regresi Linear Berganda

\begin{tabular}{llllll}
\hline \multicolumn{1}{c}{ Model } & \multicolumn{5}{c}{ Standardized } \\
& B & Std. Error & Beta & Sig. \\
\hline Constant & 0,482 & 1,193 & & & \\
$\mathrm{X}_{1}$ & 0,411 & 0,086 & 0,408 & 0,404 & 0,688 \\
$\mathrm{X}_{2}$ & 0,378 & 0,062 & 0,526 & 4,754 & 0,000 \\
$R$ Square & & & 0,697 & 6,122 & 0,000 \\
F hitung & & & 72,531 & & \\
Signifikansi F & & & $0,000^{\mathrm{b}}$ & &
\end{tabular}

Berdasarkan perhitungan statistik pada Tabel 4 dapat disusun persamaan regresi sebagai berikut.

$\mathrm{Y}=0,482+0,411 \mathrm{X}_{1}+0,378 \mathrm{X}_{2}$

Tabel 5.

Hasil Moderating Regression Analysis (MRA)

\begin{tabular}{llllll}
\hline \multicolumn{1}{c}{ Model } & \multicolumn{7}{c}{ Unstandardized Coefficients } & $\begin{array}{l}\text { Standardized } \\
\text { Coefficients }\end{array}$ & T & Sig. \\
\hline & B & Std. Error & Beta & 1,262 & 0,212 \\
\hline Constant & 4,342 & 3,440 & & 3,928 & 0,000 \\
$\mathrm{X}_{1}$ & 0,858 & 0,219 & 0,853 & 0,229 & 0,819 \\
$\mathrm{X}_{2}$ & 0,032 & 0,139 & 0,044 & $-1,765$ & 0,083 \\
$\mathrm{X}_{3}$ & $-0,659$ & 0,374 & $-0,671$ & $-1,241$ & 0,220 \\
$\mathrm{X}_{1} \mathrm{X}_{3}$ & $-0,025$ & 0,020 & $-0,630$ & 3,514 & 0,001 \\
$\mathrm{X}_{2} \mathrm{X}_{3}$ & 0,038 & 0,011 & 1,255 & & \\
$R$ Square & & & 0,780 & & \\
F hitung & & & 42,593 & &
\end{tabular}


Berdasarkan perhitungan statistik pada Tabel 5 dapat disusun persamaan regresi sebagai berikut.

$Y=4,342+0,858 X_{1}+0,032 X_{2}-0,659 X_{3}-0,025 X_{1} X_{3}+0,038 X_{2} X_{3}$

Berdasarkan Tabel 4dan Tabel 5dapat dilihat perbandingan hasil uji koefisien determinasi, dimana jika dilihat dari nilai R2, hasil uji regresi linear berganda lebih kecil daripada hasil uji regresi moderasi $(0,697<0,780)$. Masuknya variabel moderasi dan interaksi antara variabel moderasi dan variabel bebas telah menyebabkan kenaikan pada koefisien determinasi (R2). Nilai R2 dari hasil regresi moderasi digunakan untuk mengetahui seberapa besar pengaruh variabel bebas terhadap variabel terikat. Berdasarkan Tabel 5 nilai R2 sebesar 0,780, hal ini berarti $78 \%$ variasi kinerja karyawan dipengaruhi oleh variasi efektivitas sistem informasi akuntansi (X1) komitmen organisasi (X2) dan sisanya sebesar $22 \%$ dipengaruhi oleh faktor lain di luar model penelitian.

Uji kelayakan model bertujuan untuk menguji apakah model yang digunakan dalam penelitian ini layak untuk digunakan atau tidak (Ghozali, 2016). Berdasarkan Tabel 4. dan Tabel 5, baik linear berganda dan moderasi, nilai signifikansi $\mathrm{F}$ atau p-value dari kedua tabel sebesar $0,000 \mathrm{~b}$ dan $0,000 \mathrm{~b}$ yang lebih kecil dari nilai $\alpha=0,05$. Hal ini menunjukkan bahwa model regresi linear berganda dan regresi moderasi layak digunakan sebagai alat analisis untuk menguji pengaruh variabel bebas pada variabel terikat.

Pengujian terhadap pengaruh efektivitas sistem informasi akuntansi pada kinerja karyawan memperlihatkan bahwa nilai $\beta 1=0,411$ dengan tingkat signifikansi sebesar 0,000 (Tabel 4) dimana nilai signifikansi lebih kecil dari taraf 
nyata dalam penelitian ini, yaitu 0,05 , artinya bahwa hipotesis pertama (H1) dapat diterima, menunjukan efektivitas sistem informasi akuntansi berpengaruh pofitif pada kinerja karyawan. . Hal ini berarti bahwa semakin tinggi tingkat efektivitas sistem informasi akuntansi menyebabkan peningkatan kinerja karyawan bagian kliring pada Bank Peserta Kliring di Kota Denpasar Bali. Hasil penelitian ini sejalan dengan penelitian sebelumnya yang dilakukan oleh Antasari (2015) dan Suratini (2015) yang menyatakan bahwa efektivitas sistem informasi akuntansi berpengaruh positif terhadap kinerja individual. Sejalan dengan Teori Technology-to-Performance Chain (TPC) yang menyatakan suatu teknologi mempunyai dampak positif pada kinerja individual, karena teknologi akan mempermudah seorang individu dalam bekerja semakin tinggi tingkat efektivitas penerapan teknologi tersebut maka akan semakin tinggi pula kinerja yang dihasilkan.

Pengujian terhadap pengaruh komitmen organisasi pada kinerja karyawan memperlihatkan bahwa nilai $\beta 2=0,378$ dengan tingkat signifikansi sebesar 0,000 (Tabel 4) dimana nilai signifikansi lebih kecil dari taraf nyata dalam penelitian ini, yaitu 0,05, artinya bahwa hipotesis kedua $(\mathrm{H} 2)$ dapat diterima, menunjukan komitmen organisasi berpengaruh pofitif pada kinerja karyawan. Hal ini berarti bahwa semakin tinggi tingkat komitmen organisasi menyebabkan peningkatan kinerja karyawan bagian kliring pada Bank Peserta Kliring di Kota Denpasar Bali. Hasil penelitian ini sejalan dengan penelitian yang dilakukan Yuleova (2013) mengemukakan adanya pengaruh positif anatara komitmen organisasi dengan kinerja pegawai. Pengaruh yang signifikan antara komitmen organisasi dan 
kinerja karyawan juga didukung dengan penelitian yang dilakukan oleh Pahmi, Idrus dan Mahlia (2011) menemukan bahwa komitmen organisasi berpengaruh positif terhadap kinerja karyawan. Wright (1992) dalam Wasana (2015) menyatakan bahwa semakin tinggi komitmen yang dimiliki oleh individu terhadap tugasnya maka akan semakin tinggi pula kinerja yang akan dihasilkan.

Hasil uji moderasi efektivitas sistem informasi akuntansi dan locus of control(X1_X3) pada kinerja karyawan diperoleh Nilai $\beta 4=-0,025$ dengan tingkat signifikansi sebesar 0,220 dimana nilai signifikansi lebih besar dari taraf nyata dalam penelitian ini, yaitu 0,05 artinya bahwa hipotesis ketiga (H3) ditolak. Hal ini menunjukkan bahwa locus of control tidak mampu memoderasi pengaruh efektivitas sistem informasi akuntansi pada kinerja karyawan. Hasil penelitian ini sejalan dengan Lukiman (2016) yang menyatakan penerapan sistem informasi akuntansi tidak berpengaruh terhadap kinerja individual karyawan. Antasari (2015) yang menyatakan kepuasan kerja tidak mampu memoderasi pengaruh efektivitas sistem informasi akuntansi pada kinerja individual.

Efektivitas Penerapan sistem informasi akuntansi dilakukan dengan bertujuan mengurangi kekeliruan informasi yang didapat dan memberikan informasi yang akurat serta relevan, sehingga akan membantu pekerjaan seorang karyawan menjadi lebif efektif. Akan tetapi hal tersebut tidak ditunjukan pada hasil statistik, hasil statistik mengatakan bahwa locus of control tidak mampu memoderasi pengaruh efektivitas sistem informasi akuntansi pada kinerja karyawan. Hal ini terjadi karena karyawan cenderung memiliki locus of control eksternal, yang mengartikan karyawan tersebut tidak begitu yain terhadap kemampuan yang 
dimilikinya dan belum sepenuhnya yakin bahwa efektivitas sistem informasi akuntansi dapat membantunya dalam melaksankan tugasnya.

Vaariabel locus of control dalam penelitian ini tergolong dalam kelompok pure moderator. (Ghozali, 2016) menyatakan pure moderator adalah variabel moderator (Z) tidak berfungsi sebagai variabel preditor (independen) tetapi langsung berinteraksi dengan variabel predictor lainnya $(\mathrm{X})$, jenis moderator ini disebut pure moderator (moderator asli).

Locus of control merupakan cara pandang seseorang terhadap suatu peristiwa, apakah seseorang merasa dapat atau tidak mengendalikan peristiwa yang terjadi padanya (Rotter, 1996). Penyebab variabel moderasi locus of control tidak mampu memoderasi pengaruh efektivitas sistem informasi akuntansi, karena karyawan bagian kliring sudah tidak mampu mengendalikan peristiwa yang terjadi padanya, dikarenakan sistem kliring yang digunakan terus berubah-ubah sesuai dengan ketentuan Bank Indonesia dan cenderung membuat karyawan bingung, serta karyawan sudah mencapai titik nyaman menggunakan sistem yang ada sebelumnya, sehingga individu pemakai sistem tersebut tidak efektif dalam menerapkan sistem informasi akuntansi untuk kinerja yang dihasilkan.

Hasil uji moderasi komitmen organisasi dan locus of control(X2_X3) pada kinerja karyawan diperoleh Nilai $\beta 5=0,038$ dengan tingkat signifikansi sebesar 0,001 dimana nilai signifikansi lebih kecil dari taraf nyata dalam penelitian ini, yaitu 0,05. Artinya bahwa hipotesis keempat (H4) dapat diterima. Hal ini menunjukkan bahwa locus of control mampu memoderasi dan memperkuat pengaruh positif komitmen organisasi pada kinerja karyawan bagian kliring di 
bank peserta kliring Kota Denpasar Bali. Hasil penelitian ini konsisten dengan hasil penelitian yang dilakukan oleh Melizawati (2015) Ghorbanpour, Dehnavi, Forough Heyrani (2014) yang menemukan bahwa variabel komitmen organisasi mempunyai pengaruh yang positif dan signifikan terhadap kinerja karyawan

Locus of control yang dimiliki oleh karyawan bagian kliring pada bank peserta kliring di Kota Denpasar Bali akan memperkuat pengaruh positif komitmen organisasi yang dimiliki dan berdampak meningkatnya kinerja yang dihasilkan. Sejalan dengan teori atribusi yang menyatakan seseorang yang memiliki internal locus of control mampu mempengaruhi kinerja yang dihasilkan dengan kemampuan, usaha serta keahlian yang dimiliki. Semakin tinggi kemampuan yang dimiliki oleh individu tersebut, maka semakin tinggi pula komitmen yang dimiliki, sehingga menghasilkan kinerja yang tinggi.

\section{SIMPULAN}

Berdasarkan hasil pembahasan diatas dapat disimpulkan bahwa efektivitas sistem informasi akuntansi berpengaruh positif pada kinerja karyawan khususnya pada karyawan bagian kliring di Bank Peserta Kliring Kota Denpasar Bali. Komitmen organisasi berpengaruh positif pada kinerja karyawan, Locus of control tidak mampu memoderasi pengaruh efektivitas sistem informasi akuntansi pada kinerja karyawan, Locus of control mampu memoderasi pengaruh komitmen organisasi pada kinerja karyawan bagian kliring di Bank Peserta Kliring Kota Denpasar Bali.

Berdasarkan simpulan di atas, maka dapat dinyatakan beberapa saran sebagai berikut. Dari hasil penelitian ini dapat disarankan agar sistem informasi 
akuntansi yang digunakan di instansi perbankan juga harus menyediakan serta menyajikan data yang lebih rinci dan lengkap. Tujuannya untuk memudahkan karyawan khususnya karyawan bagian kliring menyelesaikan tugas pada setiap bidang pekerjaan masing-masing, karena mengingat dan sangat dibutuhkannya kliring bagi aktivitas pembayaran moneter. Selain itu, dalam meningkatkan perkembangan kinerja karyawan bagian kliring di Bank Peserta Kliring Kota Denpasar Bali sehingga selalu dipercaya oleh masyarakat sebagai instansi yang baik. Karyawan diharapkan agar mampu mempertahankan komitmen organisasi yang dimiliki, guna untuk meningkatkan kinerja yang dihasilkan karena karyawan yang memiliki komitmen yang tinggi terhadap organisasinya bisa dijadikan contoh bagi karyawan lain agar loyal terhadap organisasi dan bisa menghasilkan prestasi serta kinerja yang baik pula. Hasil $\mathrm{R}$ square sebesar 78 persen menunjukkan bahwa masih ada 22 persen faktor lain di luar model yang mempengaruhi kinerja karyawan, sehingga peneliti selanjutnya dapat menambahkan variabel yang dapat mempengaruhi dan memperkuat kinerja karyawan.

\section{REFERENSI}

Al Eqab, Mahmod and Dalia Adel. 2013. The Impact of IT Sophisticutions on the Perceived Usefulnes Of Accounting Information Characteristics among Jordanian Listed Companies. International Jurnal of Business and Social Science. 4(3), pp: 143-155.

Antasari, Kadek Chendi. 2015. Pengaruh Efektivitas Sistem Informasi Akuntansi dan Penggunaan Teknologi Informasi Pada Kinerja Individual Dengan Kepuasan Kerja Sebagai Variabel Pemoderasi. E-Jurnal Akuntansi Universitas Udayana 10.2 (2015) : 354-369. 
Asriningsih, Febri, Ni Luh Putu. 2015. Pengaruh Penggunaan Teknologi Informasi, Efektivitas Sistem Informasi Akuntansi, Sistem Pengendalian Intern Terhadap kinerja Karyawan pada Bank Perkreditan Rakyat di Kabupaten Buleleng dan Bangli. e-journal Akuntansi Universitas Pendidikan Ganesha Jurusan Akuntansi Program S1. 3(1).

Astuti , Ni Made Marlita, 2014. Pengaruh Efektivitas Penerapan Sistem Informasi Akuntasi, Pemanfaatan dan Kesesuaian Tugas dengan Teknologi Informasi terhadap Kinerja Karyawan pada Koperasi Simpan Pinjam di Kabupaten Gianyar. Skripsi. Jurusan Akuntansi Fakultas Ekonomi Universitas Udayana.

Awesejo, O.J., Kekwaletswe, R, M., Pretorius, P and Zuva, T. 2013. The Effect of Accounting Information Systems in Accounting. 3(1), pp: 142-150.

Basudewa, D. G. 2015. Pengaruh Locus of Control , Komitmen Organisasi, Kinerja Auditor, dan Turnover Intention Pada Perilaku Menyimpang Dalam Audit. Skripsi. Fakultas Ekonomi dan Bisnis Universitas Udayana.

Brownell, P. 1981. Participation in Budgeting Process, Locus of Control and Organitazional Effectivenes. The Accounting Review, 57 (4), p: 766-777

Carmeli dan Freund, 2006, Work Commitment, Job Performance: An Empirical Investigation.

Edison, G., Manuere, F, Joseph, M., and Gutu, K. 2012. Evaluation of Factors Influencing Adoption of Acounting Informasi by Small to Medium Enterprises in Chinhoyi. Journal of Contemporary Research in Bussiness, 4(6), pp: 1126-1141.

Ghorbanpour, Zahra. Dehghan, Dehnavi. Forough, Heyrani. 2014. Investigating the Effect of Organization Commitment on Performance of Auditors in the Community of Certified Accountants. Interdisciplinary Journal of Contemporary Reasearch In Business. 5(10). Pp: 109-209.

Ghozali, Imam, 2016. Aplikasi Analisis Multivariat dengan Program IBM SPSS 21. Edisi 7. Semarang: Badan Penerbit Universitas Diponegoro.

Gibson, James, L., et al. (1987) Organisasi dan Manajemen, Prilaku, Struktur, Proses. Binarupa Aksara, Jakarta.

Ginanda, Putri, Ayu. (2016) Pengaruh Sistem Informasi Akuntansi, Gaya Kepemimpinan, Kompleksitas Tugas Dan Locus Of Control Terhadap Kinerja Karyawan. Skripsi. Universitas Muria Kudus. 
Hapsari, Nanda A.R. 2010. Pengaruh Paryisipasi Penyusun Anggaran Terhadap Kinerja Manajerial dengan Komitmen Organisasi dan Locus of Control Sebagai Variabel Moderating. Skripsi. Program Sarjana Universitas Diponegoro, Semarang.

Huerryen, Yeh, Dachuan Hong. 2012. The Mediating Effect of Organizational Commitment on Leadership Type and Job Performance. 8(2). Pp: 50-59.

Jogiyanto. 2009. Sistem Teknologi Informasi. Yogyakarta. Universitas Gajah Mada. Edisi ketiga.

Kharisma dan Dharmadiaksa (2015). Pengaruh Keterlibatan Pengguna Dan Ukuran Organisasi Pada Efektivitas Pengguna Sistem Informasi Akuntansi. Issn:2302-8556. E-jurnal Ekonomi Akuntansi Univ. Udayana. 10.3:867-881 dalam portalgaruda.org diakses 17 Oktober 2017.

Kharuddin, S., Nassir, M.A., and M.Z. Ashhari. 2010. Information System and Firms Performance: The Case of Malaysian Small Medium Enterprise. International bussiness research, 3(4), 33.

Kouser, R., Awan, Shahzad, F., and A., Rana, G. 2011. Firm Size, Leverage and Profitability: Overriding Impact of Accounting Information System. Journal of Management and Bussiness review, 1(10),58-64.

Leach-López, Maria A. 2013. Moderating Effect of Hofstede's Cultural Values on the Locus of Control/ Job Performance Relationship of Managers in USA, Mexico,South Korea and Hongkong. Journal of Business Strategies, 30(1), pp: 121-134.

Lukiman, H. Lukiman. 2016. Pengaruh Penerapan Sistem Informasi Akuntansi, Pemanfaatan Sistem Informasi, Efektivitas Penggunaan Sistem Informasi Akuntansi, Kepercayaan Atas Teknologi Sistem Informasi Akuntansi dan Teknologi Informasi Terhadap Kinerja Individu Karyawan Pada Perusahaan Manufaktur Di Wilayah Tangerang. Jurnal Universitas Multimedia Nusantara. (8), pp: 60-61.

Mangkunegara, A.A. Anwar Prabu. 2000. Manajemen Sumber Daya Manusia Perusahaan. Bandung: PT Remaja Rosdakarya.

Matthieu, John E., and Zajac, Dennis M. 1990. A Review and Meta Analysis of the Antecedents, Correlates, and Consequences of Organizational Commitment. Phychological Bulletin. 108(2), pp: 171-194.

Melizawati. 2015. Pengaruh Komitmen Organisasi Terhadap Kinerja Karyawan Pada PT Indotirta Abadi Gempol Pasuruan. Skripsi. Universitas Negeri Surabaya. 
Mercika, Ni Luh Dewi Trisna, 2014. Kemudahan Penggunaan Sistem Sebagai Pemoderasi Pengaruh Efektivitas Sistem Informasi Akuntansi Terhadap Kinerja Karyawan PT BPR Sri Artha Lestari Denpasar. Skripsi Jurusan Akuntansi Fakultas Ekonomi dan Bisnis Universitas Udayana.

Ng, T. W. H., Sorensen, K. L., and Eby, L. T. 2006. Locus of control at work: A metaanalysis. Journal of Organization Behavior, 27, pp:1057-1087.

Pahmi, Idrus, Mahlia, 2011. Pengaruh Gaya Kepemimpinan dan Kepuasan Kerja Terhadp Kinerja Pegawai Melalui Komitmen Organisasi, Makasar. Skripsi. Universitas Hasanudin.

Pervin, L.A. 1963. Personality: Theory and Research. Hoboken. NJ: Wiley.

Ratna, Dita Pilih. 2014. Pengaruh Partisipasi Penyusun Anggaran Terhadap Kinerja Manajerial Dengan Budaya Organisasi dan Komitmen Organisasi Sebagai Vaiabel Moderasi Pada LPD di Kota Denpasar. Skripsi. Universitas Udayana.

Robbins, Stephen P dan Timothy A.Judge. 2015. Perilaku Organisasi (Organizational Behaviour). Jakarta: Salemba Empat.

Romney, Marshal B., dan Steinbart, Paul John. 2009. Accounting Information Sysstem. USA: Chengage Learning.

Rotter, J.B. (1966). Generalized Expenctancies for Internal Versus External Control of Reinforcement. Psychological Monographs: General and Ahlied. 80, pp: 609.

Sajady. H., Dastgir and H. Hashem Nejad. 2008. Evaluation The Effectivenessof Accounting Information System. International Journal of Information Science and Technology. 6(2). pp: 49-59.

Sanjiwani, Desak Made Putri. 2015. Pengaruh Locus of Control, Gaya Kepemimpinan dan Komitmen Organisasi pada Kinerja Auditor Kantor Akuntan Publik (KAP) di Provinsi Bali. Skripsi. Fakultas Ekonomi dan Bisnis Universitas Udayana.

Simamora, Bilson. 2003. Panduan Riset Perilaku Konsumen. Jakarta: PT Gramedia Pustaka Utama.

Simanjuntak. J. 2011, Manajemen dab Evaluasi Kinerja, Jakarta, Fakultas Ekonomi Universitas Indonesia. 
Srivastava, Shalini. 2013. Job Satisfaction and Organizational Commitment Relationship: Effect of Personality Variables. Article, Vision 17(2) pp:159167.

Sugiantara, Pande Putu Oka. Analisis Faktor-Faktor Yang Mempengaruhi Kinerja Karyawan Di Dispenda Kota Denpasar. E-Jurnal Akuntansi Universitas Udayana. Vol.20.3. pp: 2529.

Sugiyono. 2014. Metode Penilitian Bisnis. Bandung: Alfabet.

Suratini, Ni Putu Eka. 2015. Pengaruh Efektivitas Sistem Informasi Akuntansi dan Penggunaan Teknologi Informasi Terhadap Kinerja Individual pada PT. Bank Pembangunan Daerah Bali Kantor Cabang Singaraja. e-Journal Akuntansi Universitas Pendidikan Ganesha S1. 3(1).

Urquia, Grande E., Munoz, Columbia C., and Estebanez, Raquel P. 2011. The Impact of Accounting Information System (AIS) on Performance Measures: Empiricial Evidencein Spanish SMEs1. The International Journal of Digital Accounting Research, 11,25-4.

Utama, Made Suyana. 2014. Aplikas Analisis Kuantitatif. Edisi kedelapan. Diktat kuliah pada Fakultas ekonomi dan bisnis Universitas Udayana.

Vipraprastha, Tiksnayana. 2015. Pengaruh Faktor-Faktor Kinerja Individual Karyawan Terhadap Efektivitas Penggunaan Sistem Informasi Akuntansi Pada Kantor Cabang PT BNI (PERSERO) Tbk. Di Kabupaten Badung, Bali. Skripsi. Jurusan Akuntansi Fakultas Ekonomi dan Bisnis Universitas Udayana.

Widyawati, I. A. 2016. Pengaruh Komitmen Organisasi Pada Kinerja Manajerial Dengan Locus Of Control Sebagai variabel Moderasi. Skripsi. Fakultas Ekonomi dan Bisnis Universitas Udayana. 